now seems that tree seedlings on the forest floor, and understorey shade plants such as Alocasia, persist in bright light by maintaining a dynamic compromise between limited acclimation and chronic photoinhibition.

New, simplified techniques, which bring the diagnosis of photosynthetic acclimation and photoinhibition within easy reach, will permit ecophysiological analyses of these factors in vegetation dynamics. For example, disk $\mathrm{O}_{2}$ electrodes originally developed for studies of photosynthetic induction at the Research Institute for Photosynthesis, University of Sheffield, have been adapted to measure quantum yield and room-temperature fluorescence (Walker, D.A. \& Osmond, C.B. Proc. R. Soc. B, in the press). In training courses before the conference, the electrodes were applied to assess the lack of acclimation and extent of photoinhibition in ratan, an important forest product of South-East Asia which is very fastidious with regard to light. The same system has been used to probe the light responses of photosynthesis in tropical forest epiphytes, which may have a role in branch fall and gap formation. Many of these epiphytes carry out $\mathrm{CO}_{2}$ fixation via crassulacean acid metabolism (more commonly associated with succulent plants in high-light, desert habitats), which, with intrinsically high quantum yields, appears to confer photosynthetic advantages under conditions of low light and high temperature (Winter, K., Osmond, C.B. \& Hubick, K.T. Oecologia 68, 224; 1986).

Integration of these insights into the performance of tropical plants with key ecological observations, such as leaf phenology pattern $(\mathrm{R}$. Corletts, National University of Singapore) will help to define the productive structure of natural, disturbed and managed forest systems. The same ecophysiological approaches are needed to understand the role of environmental stresses, such as high temperature, inadequate nutrition and water, in limiting the productivity of agriculture of cleared land in the tropics. Even crops of tropical origin, such as maize and sorghum, perform poorly compared with temperate regions, whereas their wild counterparts such as Imperata are very aggressive. It is increasingly clear, for example, that high light intensities exaggerate the effect of stress on the photosynthetic apparatus. The light-avoiding movements of leaves of the tropical legume Siratro, which mitigate water and high temperature stress (Ludlow, M.M. \& Björkman, O. Planta 161, 508; 1984), is but one example of the ecophysiological insights that could provide a guideline for improvement of indigenous and introduced crops in the tropics.

Barry Osmond is Professor of Environmental Biology at the Australian National University, Box 475, Canberra City, ACT 2601, Australia.

\title{
Creationism
}

\section{On the tracks of men and money}

\section{from Tony Thulborn}

IN their attempts to discredit the theory of evolution, creationists have made one claim that captures the public's imagination like no other - the claim that humans coexisted with dinosaurs. The evidence for this notion is said to reside in the Cretaceous limestones (about 120 million years old) of the Paluxy River, Texas, where markings alleged to be human footprints are preserved alongside the tracks of dinosaurs. These dubious 'man-tracks' figure prominently in creationist literature and have even been featured in several films, including the widely distributed Footprints in Stone. There is no doubt that the tale of the man-tracks is one of the most popular draw-cards held by the creationists. Consequently it is surprising to learn that the tale has now been publicly renounced by a leading American creationist.

On 7 January, John D. Morris, author of a standard creationist text on the mantracks (Tracking those Incredible Dinosaurs and the People who Knew Them CLP, San Diego, 1980) made a startling confession: in a lecture at the University of New South Wales, he admitted that he could find no scientifically acceptable evidence of human tracks in the Paluxy limestones and agreed that it would be improper for creationists to continue citing mantracks as evidence against evolution. Morris repeated his conclusions in a leaflet published by the Institute for Creation Research (Impact 151, 1; 1986) and has also announced that Footprints in Stone will be withdrawn.

These welcome retractions came during the course of the 1986 Creation Science Summer Institute, a creationist symposium organized by Australia's Creation Science Foundation (CSF). Why did Morris change his mind? Apparently many of the man-tracks in the Paluxy River have now been weathered to such a degree that their true nature is becoming embarrassingly obvious: the vaguely elliptical markings heralded as human footprints have gradually weathered into the unmistakable outlines of three-toed dinosaur tracks. In the course of his lecture Morris expressed astonishment that the clarity of fossil footprints could improve, rather than deteriorate, as a consequence of natural weathering. This process is well known by professional palaeontologists but was unfamiliar to Morris, who suspected that fanatical anti-creationists had been defacing the evidence.

Morris chose to make his retraction at a crucial moment in the history of Australia's creationist movement. His forthright confession may go some way towards restoring the public image of CSF, which has suffered an onslaught of damaging criticism in past weeks. The most destructive criticisms appeared in a book (Creationism, an Australian Perspective Australian Skeptics, Melbourne, 1986) that was published only 72 hours before CSF began its summer institute. The editors of the book, Martin Bridgstock (Griffith University) and Ken Smith (Queensland University), present a series of short essays explaining the scientific and intellectual bankruptcy of CSF's arguments. More unusually, they also delve into the organization's financial dealings, based on a search of the Corporate Affairs Office in Brisbane.

The financial statements of CSF for the years 1983-84 and 1984-85 contain some intriguing facts and figures. It appears that CSF disposed of more than $\$ A 92,000$ under the heading of an 'extraordinary item' (sic). CSF still declines to give a detailed explanation of where the money went. Next, it transpires that CSF does not spend much money on scientific research. The statement for the year ending 31 March 1983 lists an outlay on research of \$A398; in the following year research expenditure soared to $\$ A 860$, less than 0.2 per cent of the organization's half-million dollar income.

Most remarkable of all is the discovery that CSF received federal government funding to the amount of $\$ A 24,698$ during the two-year period. The fact that federal funds were delivered to CSF in the form of an 'export market development grant' raises an interesting question: what does the organization intend to export? The obvious answer is that it plans to export religious materials, which is evident from the fact that CSF officially declares its principal business to be: "The preaching of the Gospel, Christian Education, the accumulation and presentation of scientific evidence relevant to Creation, publication of a magazine and the sale of books, tapes and filmstrips".

If it can be demonstrated that the exports of CSF are religious in nature it is likely that its federal funding will be ruled unconstitutional. An article in the $\mathrm{Mel}$ bourne Age (4 January 1986) reports that lawyers are now investigating the possibility of a challenge under section 116 of the Australian constitution, which expressly prohibits the government from establishing a religion.

Tony Thulborn is in the Department of Zoology, University of Queensland, St Lucia, Brisbane, Australia 4067. 